\title{
Mathematics Teaching in Primary Education Series Initials: Training in Focus
}

\author{
Arnaldo Gonçalves Matos*, Heber Cruz Silva, Paulo Henrique Dantas Freitas, \\ Rafael Frois da Silva, Fernanda Carla Lima Ferreira
}

Department of Physics, Federal University of the Southern and Southeast Para, Maraba, Brazil

Email address:

arn.goncalves@hotmail.com (A. G. Matos)

\section{To cite this article:}

Arnaldo Gonçalves Matos, Heber Cruz Silva, Paulo Henrique Dantas Freitas, Rafael Frois da Silva, Fernanda Carla Lima Ferreira. Mathematics Teaching in Primary Education Series Initials: Training in Focus. Education Journal. Vol. 4, No. 2, 2015, pp. 90-93. doi: $10.11648 /$ j.edu.20150402.16

\begin{abstract}
This work aims to analyze the (s) factor (s) which hinders (m) the learning of students entering the 6th grade of elementary school, there is a lag in terms of mathematical knowledge, especially in the four operations that are important to the understanding of other subjects such as operations with exponents etc. And one motive among many is related by the lack of trained professionals to practice math teacher role in the initial series. In the early series, professionals engaged in teaching have training in teaching degree in pedagogy. However, these early have a very diverse curriculum grades, leaving this way disciplines like mathematics in superficiality, as can be seen in pedagogy course grid Federal University of Para which only has a discipline called Theoretical and Methodological Foundations of Mathematics with 60 hours of activity. For this work, we used a literature review of articles and books that mentioned issues related to teaching in the initial series of basic education. The results indicated that some professionals, particularly pedagogues, do not have a solid background to teach the math classes, so it is recommended that the degree courses in pedagogy review their curriculum grades to meet the needs of students in the early of elementary school.
\end{abstract}

Keywords: Initial Series, Mathematics, Pedagogy

\section{Introduction}

The discrepancy of students in terms of mathematical knowledge is observed throughout the lower elementary school, and this interferes dramatically in the design and understanding of mathematics as intrinsic science to everyday life and also the applicability of mathematics as an instrumental tool for other areas of knowledge in this sense this work aims to analyze the (s) factor (s) which hinders (m) the learning of students entering the 6th grade of elementary school [1].

"We can see that mathematics is a subject that interacts with all the materials; it shows the importance of mathematics in the development of much of the educational process. Mathematics is a link that met diverse knowledge, for example, you must know the mathematic work for the population growth of a region, find the number of oxidation of a chemical element, and several other disciplines of mathematics often without realizing, however the mathematical content can also be worked so that there is an interaction between other disciplines and also the everyday as has been previously discussed [2]."

Students from 6th year of basic education who enter this level of education have serious difficulties in the four mathematical operations, a fact worrying, since the subject matter is essential to the understanding of other curriculum content that will be seen throughout the school year and as a basis for interpreting all acquired information [3], that "mathematics is an important component in the construction of citizenship, to the extent that society is used increasingly, scientific knowledge and technological resources, which citizens must take ownership."

The lack of understanding of mathematics content by the students of the initial series may be being caused by the lack of trained professionals? Since the issues related to mathematics that were part of the lower elementary school were not understood by students dynamically as mentions [3]

The starting point for the activity is not the mathematical definition, but the problem. In the process of teaching and learning, ideas, concepts and mathematical methods should be 
addressed through exploiting problems, or situations that students need to develop some kind of strategy to resolve them The problem is certainly not an exercise in which the student applies, almost mechanically, a formula or an operative procedure. Only problem if the student is led to interpret the wording of the question that may put the structure and the situation presented to him [3].

According Piovesan and Zanardini [4], the "Math is currently seen as a discipline that brings great difficulties in teaching-learning process, both for the students, as teachers involved in it."

Some students do not learn mathematics as expected by psychological factors, social and family where they live or just do not fit the methodology used by the teacher. Other students cannot learn math because they have learning disabilities or because there are learning difficulties in other areas such as reading and writing, which are little explored in the classroom $[5,6]$.

The initial series play an important role in the construction of knowledge from the earliest stages up to the preparation of students for learning math content in the later series and to assist in other areas of knowledge, because according Ambrosio [7], "the tendency of all science is increasingly to mathematically with the development of mathematical models that describe natural phenomena properly." In this sense, "it is necessary from the initial series educate taking into account the logical and deductive reasoning of the student so that the knowledge is assimilated as a natural part of everyday language and think of as important for intellectual development [8].

The students of lower primary schools have large gap of mathematical knowledge, especially in the four mathematical operations that are essential to understanding the properties inherent to the knowledge of this science so important to the improvement and understanding of other sciences that rely on mathematical tool for understanding of their phenomena.

"Mathematics as a subject present in the school curriculum has aroused investigative interests and various discussions in the educational field. It is seen as one of the key disciplines for the cognitive development of human beings. It is also notorious its application in daily life, whether in solving common problems of day-to-day, as in its scientific character, which serves as an essential tool for the construction of new knowledge and technologies [9]."

Mathematics in the initial series is usually carried out by professionals trained in teaching degree in pedagogy, ministering various disciplines of the curriculum as quotes the State Board of Education [10].

"Art. 137. Teaching in Basic Education in the State of Para Sis theme of education may be exercised by: II. Early years of elementary school: those with full degree in pedagogy, under Resolution CNE / CP no. 01/2006, as well as the full specific degrees for this level of education, according to the previous standards, accepted as the minimum training for the practice of teaching in the early years of elementary school that offered in middle level in Normal mode [10]."

As State Council of Education Resolution [10];
"Art 146. The functions of educational management, so understood those specified in Article 64 of the Law of Directives and Bases of National Education (LDBEN) administration, engineering, inspection, supervision and educational guidance for Basic Education - will be carried out by professionals: I. full licensed in Education and / or full licensed in other areas, course certificate holders graduate specially structured for this purpose under the provisions of Resolution National Education Council / CP number. 01/2006.

The process of learning mathematics in a systematic way begins in the early grades of Basic Education, where the foundations for mathematics education are built. Also according to the authors Cunha and Costa [9], in this series, in general we have as teachers in all areas of knowledge, educators who are trained professionals at a higher level, in pedagogy courses.

The Faculty of Education of the Federal University of Para, in turn, has a curriculum that includes general education characterized by Didactic, Psychologies, Sociologies, Philosophies, among others and specific training in determined areas of knowledge, which is the case of Mathematics History, Geography and Portuguese, only to exemplify [9].

In the Federal University of Para the first degree in Education in the curriculum has only one facing discipline for mathematics, called Theoretical and Methodological Foundations of Mathematics, totaling 60 hours of full activity in class, as shown in [11].

Although mathematics is present and necessary in teacher education from the initial series, it presents of juxtaposed and disjointed manner in the proposed formation of the Pedagogy course, the study institution. The isolation in which he is mathematics deflagrates a decoupled formative process of the size of the subject's students generating a fragmented formation in pedagogical practice of the Pedagogy course, which indicates that it is incorporated into the curriculum of this course, only as a supplement in the formation of pedagogue [9].

According to the research of the authors Cunha and Costa [9] "the Pedagogy course we are investigating brings into your curriculum two disciplines concerned with the study of mathematics."

Basic Mathematics in the second half of the course and Mathematics for the start of schooling offered the fourth semester, with a total workload of 135 hours, which corresponds to approximately $3.8 \%$ of the total course hours. These disciplines take different roles in pedagogical project of the course. While the former has a review character and deepening of basic contents of mathematics, the second discipline search the didactic treatment of specific mathematical content of early childhood education and the early grades of Basic Education [9].

The Federal University of Para released in the year 2009, an integrated degree course in education in science, mathematics and languages that was to train teachers for the proficuous and differentiated educational work in the early years of basic education. According to the resolution emphasizes: 
"Resolution number of 3,852 of April 29, 2009: Art. 2. The profile of graduates required by the course must include a qualified professional to guide children, youth and adults to read and write dominating techniques and technologies so that they can come to understand the world scientific and technological, as well as its means of insertion, the time to be able to dialogue with the various cultures of the students under his guidance. In addition, this professional teacher should present interdisciplinary traffic with specialists from other areas for action in educational and research projects in order to open the prospect of a permanent relationship with language, social studies, science and mathematics [12]."

The educator for is a profession of the humanities, often does not show positive attitudes towards mathematics, because during their training, the teacher does not study specific contents of Mathematics [12].

The degree in pedagogy in basic education presents several difficulties in mathematics teaching process, because their knowledge is superficial, given present lack of content in the curriculum as shown $[11,13]$. In this sense, the work of this person may be interfering in the teaching-learning process, since "the teacher in his work to create situations that encourage thinking skills of their students using alternative methods to facilitate and develop the knowledge, skills these [13]."

It is perceptible that the student should actively participate in your learning, observing, reflecting and drawing conclusions, or even that it dynamically experience the apprehension of mathematical content, and the teacher is the conductor of this process and be aware that the priority is learning significant student and not just the mere transmission of content, as can be seen in most schools [4, 5].

\section{Methodology}

For realization of this article was no need for a literature review with the use of several articles and books which focused the teaching of mathematics and its relation to the elementary school in the initial series of the basic education. The texts to support the work were selected from the 1986 to 2014 period and pedagogy course plan of the Federal University of Para.

\section{Discussion}

Licensed in pedagogy are professionals active in the function of teaching math in basic education discipline in the initial series $[9,10]$. But on the above, it is noticed that there is a great need for improvement in the teaching of initial series, because most of the teachers of these series do not have a solid background to work closely with students. However do not have a lot of skill and without broad consistency for a specific area, such as surface view of mathematics which in most cases and it was corroborated by some authors, such as mentioned Tortora et al. [14] Echeverria and Pozo [1].

The pedagogy course at the Federal University of Para and how other institutions aims to train teachers and technicians to operate in the basic education, thereby being a polyvalent professional, that even within the aforementioned federal institution is no consensus its validity as a trainer persons qualified to be a teacher function of the initial series of basic education, as can be seen in the resolution of the Federal University of Para [12].

Given the above, it can be suggested that the teaching of mathematics for teachers of elementary school of the initial series, are added or appropriate some subjects focused on the teaching of mathematics. Note that, needs to advance enough in relation to the teaching of science and mathematics in the initial series of basic education. And therefore this is not the curriculum blame the Federal University of Para and much less of educators to be having this deficiency, but due to the Brazilian educational system, it should hire more teachers to contribute in class of elementary school.

\section{Conclusion}

To teach from the mathematical discipline in the initial series the training required by the fundamental educational institutions is related to the full degree course in pedagogy, however, it is important that the course has a more significant training with concern the content, there is a charge very low horary in the curriculum focused on mathematical knowledge.

An alternative to render the course more dynamic and essential pedagogy for formation of students in the initial series that will enter the 6th year is put in the grid of the disciplines courses aimed at understanding of mathematics.

For the pedagogy course can meet the needs of students in the initial series is important that higher education institutions form teachers specifically to work in teaching and remove the grid the technical part that directs this professional to work in school management. So this way, open space to insert more math subjects in the curriculum of the degree courses in pedagogy and thus meets students with a stronger qualification.

Another suggestion would be to change the Brazilian education system with the inclusion of more teachers in the classrooms with training in various areas of knowledge for initial series of basic education. That is, besides the teacher with formation in pedagogy would be interesting to have a teacher with training in the field of exact sciences in the initial series of basic education, thus students will have a better learning in mathematics discipline.

Therefore, it is believed that the change would not only be in the curriculum of pedagogy course, but investment in Brazilian education, to train professionals to teach mathematics lessons in the initial series of basic education guarding the scientific aspect of science.

\section{References}

[1] ECHEVERRIA, M. P. P; POZO, J. I. Aprender a resolver problemas e resolver para aprender. In: POZO, J. I. (ORG) A solução de problemas. Porto Alegre: ArtMed, 1998. p.13-41. 
[2] SILVA, L. C. F. e; Monografia: As Dificuldades em Aprender e Ensinar Matemática. Disponível em: $<$ www.cdn.ueg.br/arquivos/jussara/conteudoN/1209/Monograf ia_As_Dificuldades_em_Aprender_e_Ensinar_Matematica.pd f > Acesso em: 16/08/2014

[3] PCN's: Parâmetros Curriculares Nacionais/ Ministério da Educação. Secretaria da Educação Fundamental. - $3^{\mathrm{a}}$ Ed. Brasília: A secretaria, 2001.

[4] PIOVESAN, S. B.; ZANARDINI, J. B.; O Ensino e Aprendizagem da Matemática por Meio da Metodologia de Resolução de Problemas: Algumas Considerações. Disponivel em: http://www.gestaoescolar.diaadia.pr.gov.br/arquivos/File/prod ucoes_pde/artigo_sucileiva_baldissera_piovesan.pdf $>$ Acesso em: $28 / 09 / 2014$.

[5] ONUCHIC, L de la R. Ensino-aprendizagem de Matemática a través da resolução de problemas. In: BICUDO, M. A. V. (ORG). Pesquisa em Educação Matemática: Concepções \& Perspectivas. São Paulo: Editora UNESP, 1999.

[6] DROWET, Ruth Caribe da Rocha. Distúrbios da aprendizagem. São Paulo: Ática, 1995.

[7] AMBROSIO, U. D. Da realidade à ação: reflexões sobre educação e matemática. - São Paulo: Summus; Campinas: Ed. da Universidade Estadual de Campinas, 1986.

[8] SANTOS, J. A.; FRANÇA, K. V.; SANTOS, L. S. B. dos; Dificuldades na Aprendizagem de Matemática. Disponivel em: $<$ www.educadores.diaadia.pr.gov.br/arquivos/File/2010/artigos teses/MATEMATICA/Monografia_Santos.pdf $>$ Acesso em $28 / 09 / 2014$
[9] CUNHA, D.R.; COSTA S. S. C da. A Matemática na Formação de Professores das Séries Iniciais do Ensino Fundamental: Relações entre a Formação Inicial e a Prática Pedagógica. Disponível em: < http://www.pucrs.br/edipucrs/online/IIImostra/EducacaoemCi enciaseMatematica/62905\%20-\%20DEISE\%20ROOS\%20CU NHA.pdf > Acesso em: 28/09/2014.

[10] CEE, Concelho Estadual de Educação - resolução n ${ }^{\circ} 001$ de 05 de janeiro de 2010. Governo do estado do Pará. Disponível em: <www.cee.pa.gov.br/sites/default/files/resolução\%20001\%2020 10_0.pdf > Acesso em: 14/10/2014.

[11] UFPA: Universidade Federal do Pará- Projeto Político-Pedagógico Curso De Licenciatura em Pedagogia. Disponível em: $<$ http://www.ufpa.br/cubt/publicacoes/documento/faecs/pedag ogia/PPC_PEDAGOGIA.pdf> Acesso em: 28/09/2014.

[12] PPP: Projeto Pedagógico do Curso de Licenciatura Integrada em Educação em Ciências, Matemática e Linguagens: UFPA < http://www.gemaz.obeduc.ufpa.br/femci/images/pdf/projetope dagogico.pdf > Acesso em: 10/10/2014.

[13] PERRENOUD, P. A formação dos professores no século XXI. Porto Alegre: Artmed, p.11-33, 2002.

[14] TORTORA, E.; SANDER, G. P.;PIROLA, N. A.; Um Estudo sobre as Atitudes em Relação à Matemática com alunos do Curso de Pedagogia. Disponivel em: http://sbem.esquiro.kinghost.net/anais/XIENEM/pdf/2462 17 08_ID.pdf acesso em: 03/10/2014. 